\title{
Response of Maize Cultivars to Various Nitrogen Levels
}

\section{Shakeel Ahmad ${ }^{1,2}$, Asad Ali Khan², Muhammad Kamran², Irshad Ahmad², Shahzad Ali² and Shah Fahad $^{2}$}

${ }^{1}$ Department of Agronomy, Northwest A \& F University, Yangling, China

${ }^{2}$ Department of Agronomy, The University of Agriculture, Peshawar, Pakistan

*Corresponding author: Shakeel Ahmad, Department of Agronomy, Northwest A \& F University, Yangling, China, Tel: +86 02987082869 ; E-mail: shakeel@nwafu.edu.cn

Received date: December 25, 2017; Accepted date: December 30, 2017; Published date: January 10, 2018

Copyright: (C) 2018 Ahmad S, et al. This is an open-access article distributed under the terms of the Creative Commons Attribution License, which permits unrestricted use, distribution, and reproduction in any medium, provided the original author and source are credited.

Citation: Ahmad S, Khan AA, Kamran M, Ahmad I, Ali S, et al. (2018) Response of Maize Cultivars to Various Nitrogen Levels. Eur Exp Biol Vol. 8 No. $1: 2$

\section{Abstract}

Studies pertaining to the effect of different nitrogen rates on the yield and yield components of maize cultivars (Azam and Jalal), was conducted at the New Developmental Form of The University of Agriculture Peshawar, during summer 2011 using Randomized Complete Block Design (RCBD) with split plot arrangement. The treatments comprised $0,30,60$, $90,120,150,180$ and $210 \mathrm{kgNha}^{-1}$ assigned to main plot and maize cultivars (Azam and Jalal) to sub plots. Results revealed that maximum grain ear ${ }^{-1}(383.2)$, grain yield $\left(3747.41 \mathrm{kgha}^{-1}\right)$ and harvest index $(27.66 \%)$ were recorded in Azam cultivar. However maximum ear length $(16.33 \mathrm{~cm})$, biological yield (14250 kgha-1) and thousand grain weight $(258.65 \mathrm{~g})$ were observed in Jalal cultivar. Maximum biological yield (16277.78 kg ha-1) was recorded with the application of $180-210 \mathrm{kgNha}^{-1}$. However maximum ear length $(17.18 \mathrm{~cm})$, grain ear-1 (411.32), grain yield (4888.9 $\left.\mathrm{kgha}^{-1}\right)$ and thousand grain weight $(264.96 \mathrm{~g}$ ) were observed with the application of $180 \mathrm{kgNha}^{-1}$.

Keywords: Maize; Cultivars; Nitrogen yield; yield components

\section{Introduction}

Maize, the highest yielding cereal crop in the world, is of significant importance for countries like Pakistan, where rapidly increasing population has already out stripped the available food supplies. In the cropping system, maize is the third important cereal after wheat and rice in cultivation. Among agronomic crops, maize is the most versatile one as it has great nutritive value with $72 \%$ starch, $10 \%$ protein, $4.8 \%$ oil, $8.5 \%$ fiber, $3 \%$ sugar and $17 \%$ ash. It is relatively as short duration cereal crop capable of utilizing the solar energy more efficiently. It attains great priority in the area of high altitude where chilling conditions and snow fall limits growing period of other cereals. Generally maize crop can be grown where annual precipitation exceeds $600 \mathrm{~mm}$ with well distributed over the growth period. A sandy-loam to loam soils with good organic matter is enough to hold moisture for optimum crop growth and development. Balanced nutrition is an essential component of nutrient management and plays a significant role in increasing crop production and its quality. For the major processes of plant development and yield formation the presence of nutrients like $\mathrm{N}, \mathrm{P}, \mathrm{K}, \mathrm{S}$ and $\mathrm{Mg}$, etc in balanced form is essential. Nitrogen is a component of protein and nucleic acids and its deficiency reduce growth and yield. Nunes et al. reported that biomass and grain yields of maize crop increased with increasing $\mathrm{N}$ rate. Increased application of $\mathrm{N}$ reduced barrenness and increased the shelling percentage. Bakht et al. reported that maximum number of leaves plant $^{-1}$, number of cobs plant, number of grains cob, taller plants, grain and biological yield was recorded in application of $200 \mathrm{~kg} \mathrm{~N} \mathrm{ha}^{-1}$. Ali et al. concluded that nitrogen had a significant effect on grain yield, nitrogen uptake at tasseling, maturity and in grain. There are many reasons of low productivity. Among them mismanagement of plant nutrition is considered to be the major one $[1,2]$. Hence there is a need to improve this major component of the production technology for getting higher maize production of better quality. We, therefore, intended to study effect of the $\mathrm{N}$ on maize cultivars in cereal based cropping system.

\section{Materials and Methods}

\section{Experiment location}

The study was conducted at New Developmental Farm, The University of Agricultural, Peshawar Pakistan during summer 2011. Soil of the experimental location is ecotype, namely Tarnab soil series (fine salty, mixed hyper-thermic udic haplustepts). Soil is clay loam having $1.15 \%$ organic matter with a $\mathrm{pH}$ of about 7.8 and total $\mathrm{N} 0.089 \%$. The site of experiment was located at $350 \mathrm{~m}$ above the sea level at the altitude of $34.01^{\circ} \mathrm{N}$. Topography of experimental site can be described as gently sloping from North to South [3]. The climate in general of the area is subtropical, receiving $500-700 \mathrm{~mm}$ annual precipitation with daily mean temperatures varying from $45 \pm$ $4^{\circ} \mathrm{C}$ in summer to $10 \pm 3^{\circ} \mathrm{C}$ in winter. Supplemental irrigation to 
the field provided through canal water as per crop water demand.

\section{Experimental design and treatments}

The experiment was conducted in Randomized Complete Block Design (RCBD) in split plots arrangement. Treatments were replicated four times. Main plots were consist of nitrogen level $\left(0,30,60,90,120,150,180\right.$ and $\left.210 \mathrm{kgNha}^{-1}\right)$ and cultivars (Azam and Jalal) were assigned to sub plot. Subplot size was five rows four meter wide and five meter long. Sowing was done during 1st week of July 2011 [4]. Half dose of nitrogen was applied at the time of sowing and the remaining half was applied when the crop was at knee height stage. Irrigation and all other agronomic practices were carried out uniformly throughout the growing season.

\section{Statistical analysis}

Data on growth and yield components were collected using standard procedures and were analyzed statistically by using
Fisher's analysis of variance technique. Least significant difference test at 0.05 probability was employed to test the significance of treatment's means.

\section{Results and Discussion}

\section{Ear length}

Table 1 showed that nitrogen and cultivars had significant effect on ear length of maize. Interaction between nitrogen levels and cultivars were non-significant. Maximum ear length was recorded in Jalal compared to Azam. Generally ear length decrease with decrease in nitrogen levels. High ear length was recorded in the treatment of $180 \mathrm{kgNha}^{-1}$. Minimum ear length was recorded in control plot. The probable reason could be that at favorable environment optimum utilization of solar light, higher assimilated production and its conversion to starches resulted higher ear length as reported by Derby et al. [5]. The results are also in agreement with Turgut, who reported increase in nitrogen levels positively influence ear length of maize.

Table 1: Effect of Nitrogen levels on Agronomic traits of two maize cultivars.

\begin{tabular}{|c|c|c|c|c|c|c|}
\hline Treatments & Ear length $(\mathrm{cm})$ & Grain ear ${ }^{-1}$ & $\begin{array}{l}1000 \text { grain weight } \\
\text { (g) }\end{array}$ & $\begin{array}{l}\text { Grain yield (kg } \\
\left.\mathrm{ha}^{-1}\right)\end{array}$ & $\begin{array}{l}\text { Biological yield } \\
\left(\mathrm{kgha}^{-1}\right)\end{array}$ & Harvest index \\
\hline \multicolumn{7}{|l|}{ Cultivars } \\
\hline Azam & $15.59 b$ & $383.20 a$ & $252.86 b$ & $3757.41 a$ & $13388.89 b$ & $27.66 a$ \\
\hline Jalal & $16.33 a$ & $375.65 b$ & $258.66 a$ & $3687.09 \mathrm{~b}$ & $14250 a$ & $25.23 b$ \\
\hline LSD & 0.72 & 7.5 & 2.71 & 60.77 & 513.31 & 1.33 \\
\hline \multicolumn{7}{|l|}{$\mathrm{N}$-levels } \\
\hline 0 & $14.29 \mathrm{c}$ & $307.33 e$ & $251.08 c$ & $1615.55 \mathrm{~g}$ & $9555.55 d$ & $17.42 \mathrm{e}$ \\
\hline 30 & $15.14 \mathrm{bc}$ & $381.52 c$ & $234.04 d$ & $2367.22 f$ & $11388.89 c$ & $20.82 d$ \\
\hline 60 & $15.40 \mathrm{bc}$ & $356.70 d$ & $264.16 a b$ & $3115.25 \mathrm{e}$ & $11500 c$ & $27.66 \mathrm{bc}$ \\
\hline 90 & 16.27ab & $383.75 \mathrm{bc}$ & $264.18 a b$ & $3959.74 d$ & $14833.33 b$ & $26.96 c$ \\
\hline 120 & 16.70ab & $388.42 \mathrm{bc}$ & $251.27 c$ & $4715.30 \mathrm{~b}$ & $15055.56 \mathrm{ab}$ & $31.44 a$ \\
\hline 150 & 16.52ab & $409.12 a$ & $257.98 b$ & 4773.08ab & $15722.22 \mathrm{ab}$ & $30.48 a b$ \\
\hline 180 & $17.18 a$ & $411.32 a$ & $264.96 a$ & $4888.97 a$ & $16222.22 a$ & $30.27 a b$ \\
\hline 210 & 16.23ab & $397.23 a b$ & $255.57 \mathrm{bc}$ & $4302.87 c$ & $16277.78 a$ & $26.51 \mathrm{c}$ \\
\hline LSD & 1.69 & 15.38 & 6.46 & 133.22 & 1294.17 & 3.23 \\
\hline
\end{tabular}

\section{Grain ear ${ }^{-1}$}

Number of grain ear ${ }^{-1}$ was significantly affected by nitrogen levels and maize cultivars. High number of grains ear ${ }^{-1}$ was recorded in the plots treated with $150 \mathrm{~kg}$ and $180 \mathrm{kgNha}^{-1}$. Minimum number of grains ear $^{-1}$ was recorded in control. The higher number of grains ear ${ }^{-1}$ were recorded in Azam compared to Jalal. Interaction between cultivars and nitrogen levels was non-significant.the results are in agreement with Muhammad et al. [6] who stated that $180 \mathrm{kgN}$ gives higher number of grain ear $^{-1}$. Increase in grains ear ${ }^{-1}$ from higher nitrogen levels might be due to the lower competition for nutrients that allowing the plants to accumulate more biomass with higher capacity to convert more photosynthates into sinks resulting in more grains $\mathrm{cob}^{-1}$. These results are also in agreement with Zeidan et al. [7] who reported that grain number per cob was highest at the highest nitrogen level.

\section{Thousand grain weight}

Thousand grain weights were significantly affected by cultivars and nitrogen levels. The interaction between cultivars and nitrogen levels was significant (Figure 1). Mean value of the data indicated maximum thousand grain weights $(264.96 \mathrm{~g})$ with application of $180 \mathrm{kgNha}^{-1}$, followed by $150 \mathrm{kgNha}^{-1}$ (257.18 g). Minimum thousand grain weight $(251.08 \mathrm{~g})$ was recorded in 
control. The effect of cultivars on thousand grain weight was significant. Highest thousand grain weight was observed in Jalal variety as compared to Azam variety. The results are in agreement with those Muhammad et al. [8] who found that $\mathrm{N}$ when applied at the rate of $180 \mathrm{kgha}^{-1}$ significantly increases the thousand grain weight. The differences in grain weight of maize cultivars might be due to different nitrogen application could be attributed to variation in nutrition. These results are supported by Sharar et al. [9] who reported that by the increase in $\mathrm{N}$ dose the 1000-grain weight showed increase.

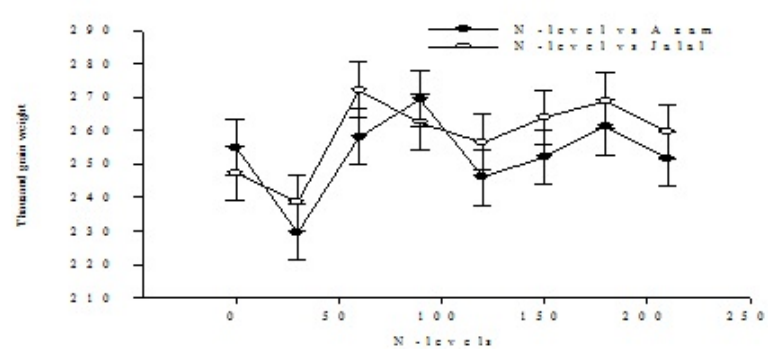

Figure 1: Mean comparison of interaction of various levels of nitrogen fertilizer on thousand grain weight of maize cultivars.

\section{Grain yield}

Effect of nitrogen levels and cultivars was significant on grain yield. Interaction of cultivar and nitrogen was found significant (Figure 2). Highest grain yield $\left(4888 \mathrm{kgha}^{-1}\right)$ was recorded with the application of $150 \mathrm{kgNha}^{-1}$ and $180 \mathrm{kgNha}^{-1}$ with grain yield (4773 and $488.97 \mathrm{kgha}^{-1}$ respectively). Lowest grain yield (1615 $\mathrm{kgha}^{-1}$ ) was recorded in control plot. The effect of cultivars on grain yield was also significant. The maximum grain yield was recorded in Azam variety as compared to Jalal. Application of $180 \mathrm{kgNha}^{-1}$ showed a significant increase in grain yield when compared with control treatment Muhammad et.al. [8].

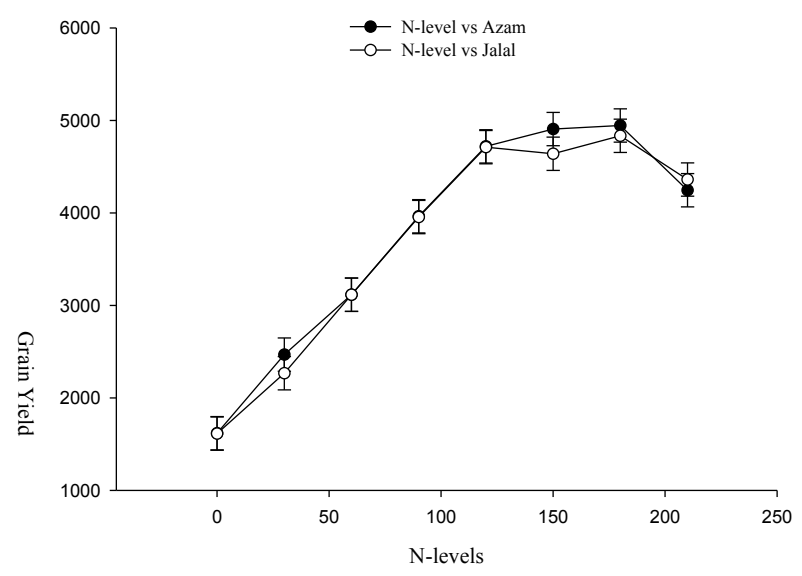

Figure 2: Mean comparison of interaction of various levels of nitrogen fertilizer on grain yield of maize cultivars.
Younas et al. [10] and Mkhabela et al. reported that high levels of nitrogen enhanced the grain yield on account of increased number of grains ear-1. Younas et al. [10] and Mkhabela et al. reported that high levels of nitrogen enhanced the grain yield on account of increased number of grains ear ${ }^{-1}$.

\section{Biological yield}

Effect of nitrogen levels and cultivars was significant on biological yield $\left(\mathrm{kgha}^{-1}\right)$. Mean value of the data showed maximum biological yield (16277 $\left.\mathrm{kgha}^{-1}\right)$ from the treatment of $210 \mathrm{kgNha}^{-1}$, followed by $150 \mathrm{kgNha}^{-1}$ with biological yield (15722 kgha-1). Minimum biological yield (9555 kgha-1) was recorded in control. The effect of cultivars on biological yield was significant. Highest biological yield was recorded in Jalal variety as compared in Azam variety. The interaction between cultivars and nitrogen levels was non-significant [11,12]. Biological yield increase with increase in $\mathrm{N}$-levels because of more vegetative growth occur which results in increased in biological yield.

\section{Harvest index}

Harvest index of a crop is an interaction of its physiological efficiency and its ability of converting the photosynthetic material into economic yield. Effect of nitrogen levels and cultivars on harvest index was significant. Maximum harvest index (31.44\%) was recorded with the application of 120 $\mathrm{kgNha}^{-1}$, followed by $150 \mathrm{kgNha}^{-1}(30.48 \%)$. Minimum harvest index $(17.42 \%)$ was recorded in the control plot. The effect of variety on harvest index was also significant. Mean value of the data showed maximum harvest index in Azam variety as compared to Jalal variety [13]. The interaction between cultivars and nitrogen levels were non-significant. These results was reported Masood et al. [14] who found that plot treated with $\mathrm{N}$ levels of $120 \mathrm{kgNha}^{-1}$ produced maximum harvest index.

\section{Summary}

The experiment entitle "response of maize cultivars to various nitrogen levels" was conducted at New Developmental Farm, Khyber Pakhtunkhwa Agricultural University Peshawar Pakistan, during the year 2011. The experiment was carried out in RCB design spilt plot having four replications. Treatments were replicated four times. Main plots were consist of nitrogen level $\left(0,30,60,90,120,150,180\right.$ and $\left.210 \mathrm{kgNha}^{-1}\right)$ and cultivars (Azam and Jalal) were assigned to sub plot. Subplot size was five rows four meter wide and five meter long. Sowing was done during 1st week of July 2011. Half dose of nitrogen was applied at the time of sowing and the remaining half was applied when the crop was at knee height stage. Irrigation and all other agronomic practices were carried out uniformly throughout the growing season. The various parameters studied were Ear length $(\mathrm{cm})$, number of grain ear ${ }^{-1}$, thousand grains weight $(\mathrm{g})$, grain yield $\mathrm{kg} \mathrm{ha} \mathrm{h}^{-1}$, Biological yield $\mathrm{kg} \mathrm{ha}^{-1}$ and harvest index \%. Statistical analysis of the data revealed that that maximum grain ear $^{-1}$, grain yield $\mathrm{kgha}^{-1}$ ) and harvest index (\%) were recorded in Azam cultivar. However maximum ear length $(\mathrm{cm})$, biological yield $\left(\mathrm{kgha}^{-1}\right)$ and thousand grain weight $(\mathrm{g})$ were observed in 
Jalal cultivar. Maximum biological yield $\left(\mathrm{kgha}^{-1}\right)$ was recorded with the application of $80-210 \mathrm{kgNha}^{-1}$. However maximum ear length $(\mathrm{cm})$, grain ear-1, grain yield $\left(\mathrm{kgha}^{-1}\right)$ and thousand grain weight (g) were observed with the application of $180 \mathrm{kgNha}^{-1}$.

\section{Conclusion}

Among the nitrogen sources urea $\left(180 \mathrm{kgNha}^{-1}\right)$ showed best results on production of maize crop while Aam cultivar showed best performances on production as compared to Jalal and thus recommended for general use to enhance the growth and productivity of Maize crop in Peshawar valley.

\section{References}

1. Ali J, Bakht J, Shafi M, Khan S, Ali W (2002) Uptake of nitrogen as affected by various combination of nitrogen and phosphorous. Asian J Plant Sci 1: 367-369.

2. Bakht J, Ahmad S, Tariq M, Akber H, Shafi M (2006) Response of maize to planting methods and fertilizer N. Journal of Agricultural and Biological Science 1: 8-14.

3. Chaudhry AR (1983) Maize in Pakistan. Punjab Agricultural Board Research Coordination Board, University of Agriculture, Faisalabad, Pakistan.

4. Derbay N, Casey FX, Kinghton RE, Steel DD (2004) Midseason nitrogen fertility management for corn based on weather and yield predication. Agron J 96: 494-502.

5. Haseeb UR, Asghar A, Muhammad W, Asif T, Muhammad AN, et al. (2010) Impact of nitrogen on growth and yield of maize grown alone and combination of cow pea. American-Eurasiant J Agric and Environ Sci 7: 43-47.
6. Mahmood T (1994) Impact of water and nutrient management on growth, yield and quality of maize (Zea Mays L) PhD Thesis, Department of Agronomy, University of Agriculture, Faisalabad.

7. Masood M, Shams IH, Hussain N, Shah WA (2003) Performance of Various maize cultivars as Affected by Different NP levels. Asian journal of plant Sciences 2: 535-538.

8. Muhammad J, Khan H, Ali A, Ahmad M, Raziq F (2009) Response of various maize cultivars to different levels of Nitrogen against biopalarus maydis (NISIK) shoemaker under natural epiphototic conditions. Sarhad J Agri 25: 243-249

9. Nunes GHS, Silva PSL, Nunes SGH (1996) Response of maize to nitrogen levels and weeds control. Ciencia-e-Agrotecnologia 20: 205-211.

10. Randhawa PS, Arora CL (2000) Phosphorus-sulfur interaction effects on dry matter yield and nutrient uptake by wheat. Journal of Indian Society of Soil Science 48: 536-540.

11. Steel RGD, Torrie JH (1984) Principles and Procedures of Statistics. McGraw Hill Book Co Inc, New York 336.

12. Sharar M, Ayub SM, Nadeem M, Ahmad N (2003) Effect of different rates of nitrogen and phosphorus on growth and grain yield of maize (Zea mays L). Asian J Plant Sci 2: 347-349.

13. Younas M, Rehman H, Hayder G (2002) Magnitude of variability for yield and yield associated traits in maize hybrids. Asian J Plant Sci 1: 694-696.

14. Zeidan MS, Amany A, Bahr M, Kramany FE (2006) Effect of Nfertilizer and plant density on yield and quality of maize in sandy soil Res J Agric and Biol Sci 2: 156-161. 